\title{
KHAZANAH FILSAFAT DALAM TRADISI ISLAM
}

\author{
Muhammad Fadli Fajrin \\ Sekolah Tinggi Agama Islam Darul Da'wah Wal-Irsyad (STAI DDI) Kota Makassar \\ Email : $\underline{\text { muhfadlifajrin1234@gmail.com }}$ \\ Nasuha \\ Sekolah Tinggi Agama Islam Darul Da'wah Wal-Irsyad (STAI DDI) Kota Makassar \\ Email : nasuha2801@gmail.com \\ Dosen Pembimbing :Ibnu Hajar Sainuddin \\ Sekolah Tinggi Agama Islam Darul Da'wah Wal-Irsyad (STAI DDI) Kota Makassar \\ Email : ibnuhajar@staiddimakassar.ac.id
}

\begin{abstract}
ABSTRAK
Penamaan filsafat telah menjadi perbincangan dikalangan ilmuan, terutama dikalangan orientalisme Barat sejak abad 19 lalu. Namun sebelum membahas polemik penamaan ini, kita perlu melihat makna "filsafat" itu sendiri. Sebab gagal paham dengan istilah ini, akan tambah kebingungan dalam memahmi istilah Filsafat Islam. Kata Filsafat berasal dari bahasa Yunani yang terdiri dari dua kata yaitu 'Filein' yang bermakna cinta dan 'sophia' yang bermakna kebijkasanaan, sehingga orang yang bijak disebut Sofis.
\end{abstract}

\section{Kata Kunci : Filsafat, Kazanah, Tradisi Islam}

\section{A. Pendahuluan}

. Penamaan filsafat telah menjadi perbincangan dikalangan ilmuan, terutama dikalangan orientalisme Barat sejak abad 19 lalu. ${ }^{1}$ Namun sebelum membahas polemik penamaan ini, kita perlu melihat makna "filsafat" itu sendiri. Sebab gagal paham dengan istilah ini, akan tambah kebingungan dalam memahmi istilah Filsafat Islam. Selain itu kita juga harus pandai dalam melihat sisi pandang etika dan filsafat yang telah dipaparkan oleh Syekh Yusuf

\footnotetext{
${ }^{1}$ Damyati, A. R. (2018). "Atomisme" Dan "Hilomorfisme” Dalam Diskursus Pemikiran Islam1. Al-Irfan: Journal of Arabic Literature and Islamic Studies, 1, 97-120.
} 
Al-Makassari. ${ }^{2}$ Kata Filsafat berasal dari bahasa Yunani yang terdiri dari dua kata yaitu 'Filein' yang bermakna cinta dan 'sophia' yang bermakna kebijkasanaan, sehingga orang yang bijak disebut Sofis. Kononnya Pythagoras tidak setuju dikatakan sebagai seorang sofis sebagai orang bijak, ia mengatakan bahwa dirinya bukanlah hakim. Pythagoras menganggap penyebutan hakim hanyalahlah tuk Tuhan saja dan orang yang disebut hakim sama artinya menyayingi Tuhan, hingga ditambahlah kata 'filo' yg artinya pecinta, maka jadilah 'filosofi' pecinta kebijkasanaan. Kata 'filosofi' akhirnya menjadi ngetren sebagai lawan sofis. meski sebenarnya tak berlawan secara makna namun secara pencitraan bertentangan, sehingga jikalau kita menyebut sofis artinya itu buruk.

\section{B. Pembahasan}

\section{Filsafat Islam}

Filsafat Islam juga sering disebut Filsafat Arab dan Filsafat Muslim merupakan suatu kajian sistematis terhadap kehidupan, alam semesta, etika, moralitas, pengetahuan, pemikiran, dan gagasan politik yang dilakukan di dalam dunia Islam atau peradaban umat Muslim dan berhubungan dengan ajaran-ajaran Islam lainnya seperti pelestarian lingkungan sebagai implementasi dakwah bi al-hal dan wujud kesadaran masyarakat. ${ }^{3}$

\section{Khazanah}

Khazanah atau juga yang sering disebut dengan ruang kulis adalah sebuah karya bangunan atau ruangan dengan konstruksi baja yang sangat kuat. Khazanah memiliki system keamanan berlapis untuk menyimpan uang, dokumen penting atau surat

\footnotetext{
${ }^{2}$ Sainuddin, I. H., S, Wekke, I. S., \& Rajjako, A. (2020, August 10). Syekh Yusuf Al-Makassari: Pandangan Etika dan Filsafat. https://doi.org/10.31219/osf.io/g8cuk

${ }^{3}$ Alwi, A. M. S., Arsyam, M., \& Sainuddin, I. H. S, \& Makmur, Z.(2020, August 18). PELESTARIAN LINGKUNGAN SEBAGAI IMPLEMETASI DAKWAH BI AL-HAL DAN WUJUD KESADARAN MASYARAKAT.
} 
berharga. Khazanah biasanya ada di Bank dan digunakan untuk tempat penyimpanan milik bank maupun nasabah.

3. Tradisi Islam

Tradisi adalah kebiasaan atau adat istiadat yang dilakukan turun temurun oleh masyarakat. ${ }^{4}$ Sebagaimana diketahui bahwa sebelum Islam datang, masyarakat Nusantara sudah mengenal berbagai kepercayaan dan memiliki beragam tradisi lokal. Melalui kehadiran Islam maka kepercayaan dan tradisi di Nusantara tersebut membaur dan dipengaruhi nilai-nilai Islam. Karenanya muncullah tradisi Islam Nusantara sebagai bentuk akulturasi antara ajaran Islam dengan tradisi lokal Nusantara. Adapun pengembangan masyarakat islam yang telah di paparkan oleh tokoh agama yang paling terkenal di daerah Makassar ialah Syekh Yusuf Al-Makassari. ${ }^{5}$

\section{Kesimpulan}

Filsafat Islam artinya berpikir dengan bebas dan radikal namun tetap berada pada makna, yang mempunyai sifat, corak, serta karakter yang menyelamatkaan dan memberi kedamaian hati yang tetap berlandaskan pada Al-Qur'an dan As-Sunah. Filsafat islam itu adalah suatu nama umum dari filsafat-filsafat yang dikembang dalam kultur dan perdaban islam.

Ahli barat berpendapat bahwa keberadaan tradisi dalam islam hanya meniru filsafat yunani. Tetapi islam menjadikan Al-Quran dan sunnah sebagai dasar. Dan bukan hanay sumber tertinggi keagamaan melainkan menjadikannya sebagai hakikat eksistensi dan sumber segala eksistensi. Jadi, meskipun islam terpengaruh dari prmikirn yang berasal dari yunani dan

\footnotetext{
${ }^{4}$ Taufik, T., Katu, S., \& Santalia, I. (2018). FENOMENA TRADISI ZIARAH PADA KUBURAN PETTA BETTA'E PADA MASYARAKAT KABUPATEN BONE. Jurnal Diskursus Islam, 6(1), 1-18.

${ }^{5}$ Sainuddin, I. H., S, Arsyam, M., Wekke, I. S., \& Rajjako, A. (2020, August 24). Syekh Yusuf Al-Makassari; Pengembangan Masyarakat Islam. https://doi.org/10.31219/osf.io/mg8f6
} 
helenisme, bukan berarti islam meniru selurunya pemikiran filsafat sebelumnya karena filsafat islam berasaskan Al-Quran dan sunnah, isu isu dalam filsafat islam direspon dalam perspektif islam, terdapat masalah yang khas yang merupakan karya orsinil para filusif islam. 


\section{DAFTAR PUSTAKA}

Damyati, A. R. (2018). "Atomisme" Dan "Hilomorfisme" Dalam Diskursus Pemikiran Islam1. Al-Irfan: Journal of Arabic Literature and Islamic Studies, 1, 97-120.

Sainuddin, I. H., S, Wekke, I. S., \& Rajjako, A. (2020, August 10). Syekh Yusuf Al-Makassari: Pandangan Etika dan Filsafat. https://doi.org/10.31219/osf.io/g8cuk

Alwi, A. M. S., Arsyam, M., \& Sainuddin, I. H. S, \& Makmur, Z.(2020, August 18). PELESTARIAN LINGKUNGAN SEBAGAI IMPLEMETASI DAKWAH BI AL-HAL DAN WUJUD KESADARAN MASYARAKAT.

Taufik, T., Katu, S., \& Santalia, I. (2018). FENOMENA TRADISI ZIARAH PADA KUBURAN PETTA BETTA'E PADA MASYARAKAT KABUPATEN BONE. Jurnal Diskursus Islam, 6(1), 1-18.

Sainuddin, I. H., S, Arsyam, M., Wekke, I. S., \& Rajjako, A. (2020, August 24). Syekh Yusuf Al-Makassari; Pengembangan Masyarakat Islam. https://doi.org/10.31219/osf.io/mg8f6 